\title{
THE RELATIONSHIP BETWEEN FIFTH GRADE STUDENTS' NUMBER SENSE AND THEIR MATHEMATICAL PROBLEM SOLVING
}

\author{
Annisa Mutmainnah', Zetra Hainul Putra ${ }^{2}$, Syahrilfuddin $^{3}$ \\ ${ }^{1}$ Universitas Riau \\ ${ }^{2}$ Universitas Riau \\ ${ }^{3}$ Universitas Riau \\ ${ }^{1}$ mutmainnahannisaa@gmail.com, ${ }^{2}$ zetra.hainul.putra@lecturer.unri.ac.id , \\ ${ }^{3}$ syahrilfuddin@lecturer.unri.ac.id
}

\begin{abstract}
This research was aimed to find out the relationship between the fifth grade students' number sense and their mathematical problem solving. The participants of this study were 73 fifth grade students from a private Islamic school in Pekanbaru, Indonesia. The research method used is in the form of quantitative methods. The instrument in this study is a test, where the data collected by distributing a test about students' number sense and their mathematical problem solving. Number sense indicators consist of number concepts, multiple representations, effects of operations, equivalent expressions, and computing and counting strategies. The problem solving materials consist of numbers, fractions, geometry, and measurements. The data analysis technique is done by presenting data, normality test, linearity test, linear regression test, and hypothesis testing using the Pearson product moment correlation. The results showed that there was a significant correlation between students' number sense and their mathematical problem solving. After that, a correlation test is performed between all number sense indicators with mathematical problem solving materials. The indicator of computing and counting strategies has high correlation with measurement.
\end{abstract}

Keywords: Correlation, Number Sense, Problem solving

\begin{abstract}
Abstrak
Penelitian ini bertujuan untuk mengetahui hubungan antara kemampuan number sense dan kemampuan pemecahan masalah matematika siswa kelas V. Partisipan penelitian ini berjumlah 73 siswa kelas lima dari sebuah sekolah Islam swasta di Pekanbaru, Indonesia. Metode penelitian yang digunakan berupa metode kuantitatif. Intrumen dalam penelitian ini adalah tes, dimana data dikumpulkan dengan mendistribusikan tes tentang kemampuan number sense dan kemampuan pemecahan masalah matematika mereka. Indikator kemampuan number sense terdiri dari konsep angka, representasi ganda, efek operasi, persamaan ekspresi, dan strategi komputasi dan penghitungan. Materi tes pemecahan masalah terdiri dari bilangan, pecahan, geometri, dan pengukuran. Untuk teknik analisis data dilakukan dengan penyajian data, uji normalitas, uji linieritas, uji linier regresi, dan uji hipotesis yang dilakukan dengan menggunakan korelasi pearson product moment., Hasil penelitian menunjukkan bahwa terdapat korelasi yang signifikan antara kemampuan number sense dan kemampuan pemecahan masalah matematika siswa. Setelah itu, uji korelasi juga dilakukan antara semua indikator kemampuan number sense dengan seluruh materi pemecahan masalah matematika. Korelasi tertinggi yang diperoleh yaitu korelasi antara indikator komputasi dan penghitungan dengan materi pengukuran.
\end{abstract}

Kata Kunci: Korelasi, Number sense, Kemampuan pemecahan masalah

\section{INTRODUCTION}

Mathematics in primary school has a scope that includes numbers, geometry, measurements, and data processing. Numbers are the basic components of mathematics because of the basis of mathematics (Purnomo, 2013). It is important to master the numbers in 
learning mathematics. It does not only recognize numbers and is skilled in counting, but also understands the properties of numbers, has a good intuition about numbers, and also knows the relationships between numbers. This sensitivity to numbers and calculations is known as the ability of number sense.

Number sense can be defined as a student's understanding of numbers and number operations with the ability to use these understandings flexibly in making mathematical decisions and developing useful and efficient strategies in managing questions related to numbers (McIntosh, Bana, \& Farrell, 1997; McIntosh, Reys, \& Reys, 2005). Correspondingly, Dehaene (in Tonra, 2016) states that humans must have an understanding of number sense and must be nurtured to assist and support the future development of mathematical thinking and its application. So, the ability to number sense, which if properly trained and developed, will be beneficial for students because it is terrific to support students' intelligence thinking. Students with a good number sense ability will be skilled in solving math problems. They can do the calculations according to the needs and practical calculations, not only encouraged by using routine calculations, but also to use their understanding of numbers to solve mathematical problems that are not limited by traditional algorithms or procedures (Safitri, Mulyati, \& Chandra, 2017).

Several previous studies have shown that students' ability of the number sense was low (Safitri et al., 2017; Witri, Putra, \& Nurhanida, 2015). Students have lack of understanding related to numbers and operations and had lack of understanding of the relationship between the context of the problem and the calculations needed and no awareness of some efficient strategies and methods in solving math problems. Witri et al., (2015) found that fifth-grade students had low number sense abilities, especially in the concept of fractions.

In this study, we are interested in studying students' ability of number sense and its relation to their ability to solve mathematical problems. By following what was explained by Safitri et al., (2017) that the ability of a good number sense can help students be skilled in solving math problems by making calculations more effective. Problem-solving is one of the abilities that students must master. Soedjadi (2000) explains that the ability to solve mathematical problems is a skill in students to be able to use mathematical knowledge (including numbers) to solve problems in mathematics, problems in other sciences and also problems in everyday life. In this case, number sense provides an essential role in solving these mathematical problems. Someone with excellent number sense abilities will eventually be able to utilize their knowledge of numbers in various situations, especially in solving mathematical 
problems. Thus, the research question for this study is to what extend the relationship between students' number sense and their mathematical problem solving?

\section{Number Sense}

Number sense is a student's understanding of numbers and number operations in the ability to use that understanding flexibly to make mathematical decisions and develop strategies that are useful in solving problems related to numbers (McIntosh et al., 1997, 2005). Another definition is also explained by Yang and Hsu (in Habibah, 2016) which states that number sense refers to a person's general understanding of numbers and their operations and ability to deal with everyday situations related to numbers. This ability is divided into the ability to use strategies that are useful, flexible, and also efficient in making calculations and estimates to deal with numerical problems.

Amirulloh and Budiarto (2013) explain some of the benefits of number sense, namely: 1) understand the numbers thoroughly, namely understanding numbers starting from the definition, how to represent numbers, the relationship between numbers, and knowing the number system, 2) understanding number operations, that is understanding the definition of number operations and the use of number operations correctly in everyday life. 3) resolve problems quickly, namely, students who have good number sense will affect the smoothness of calculations and make thought for problem-solving for the better.

In general, there are five components to measure the ability of students' number sense (McIntosh et al., 2005). The five components are used as instructional in this study, namely:

1. Understand the meaning of numbers, number operations and relationships between numbers.

2. Able to use various representations and number operations.

3. Get to know the relative size of numbers.

4. Being able to decompose and compose numbers flexibly.

5. Being able to decide wisely the results of calculations through different strategies.

From the components of number senses described by McIntosh et al., (2005) and Yang, Hsu, and Huang (2004), we develop number sense ability indicators, where the indicators are used as a reference for this study. 


\section{Mathematical Problem Solving}

Problem solving is defined as an activity carried out by changing one's perspective on the problem to identify the problem, which is then decided on how to solve the problem (Polya, 1983; Robson \& Polya, 1946). According to Polya, the solution provided is not only an answer to solve a problem but also contains a procedure that must be done to get an answer. For this reason, the answer giver or the one who resolves the problem must provide detailed resolution steps. There are four steps students must take to solve a given problem, namely: : (1) understanding the problem, (2) devising a plan, (3) carrying out the plan that has been made, and (4) looking back at all the processes carried out.

The ability to solve mathematical problems is a skill in students to be able to use mathematical activities to solve problems in mathematics, problems in other sciences and also problems in daily life (Putra, Darmawijoyo, Putri, \& den Hertog, 2011; Putra \& Witri, 2019; Soedjadi, 2000). Posamentier and Krulik (2009) in his book entitled Problem Solving in Mathematics Grades 3-6 explains that problem solving strategies have been divided into nine strategies. Something similar is explained in Syahlan (2017) Syahlan (2017) and Umar (2016) which are as follows: organizing the data, intelligent guessing and testing, solving a simple, equivalent problem, acting it out/ simulating the action, working backward, finding a pattern, logical reasoning, making a drawing, and adopting a different point of view.

\section{METHOD}

The type of research used in this study is a quantitative research method, specifically the correlational method. The correlational study is research that is intended to determine whether there is a relationship between the two variables used, namely the ability of number sense as an independent variable (X) and the ability to solve mathematical problems as a dependent variable (Y).

The population in this study was 73 students in the fifth grade from a private Islamic school in Pekanbaru, Indonesia. Furthermore, the sample was taken using a saturated sample technique where all members of the population were sampled namely 73 students consisting of 38 male students and 35 female students. The age of the sample students ranged from 11 to 12 years, all of whom were born in 2008 and 2009. In mathematics learning, the sample students had learned about numbers, number operations, different types of fractions, fraction operations, measurements (length, time, and weight), get up flat and build space. 
The first step taken by researchers is to prepare research instruments in the form of number sense ability test questions and mathematical problem solving ability test questions. The first researcher tested the problems to 10 non-sample students and conducted a semistructured interview to get an insight of their difficulties and challenges in solving those tasks. Then, the instruments was revised with the expert team. The number sense ability test instrument that were tested on sample students was developed based on the number sense indicator and also seen from previous studies conducted by Nurhanida, Witri, and Alpusari (2017) and Witri et al., (2015) where there were 20 questions in the form of objective. As for tests of mathematical problem-solving abilities, researchers adapted Posamentier and Krulik's questions (2009) and also designed our own questions, which included 4 mathematical learning content, namely numbers, fractions, measurements, and geometries, with a total of 20 questions and essays.

Data analysis techniques in this study are using statistics with the following stages: (a) Presentation of data, After obtaining data on a number sense ability test and a mathematical problem solving ability test, the researcher then performs a scoring and recapitulates, (b) Calculates the mean, standard deviation, median, minimum and maximum values, and (c) Percentage of number sense abilities and mathematical problem solving.

Further analysis prerequisite tests were conducted including: (a) normality test, normality test using the Kolmogorov Smirnov technique (Sugiyono, 2014) with the help of SPSS version 25 computer program. Data are stated as a normal distribution if the probability value is above a significant level of $\alpha=0.05$. (b) Linearity, the testing criteria is if the significant coefficient of linearity is less than 0.05 , then the linearity test is suitable for use in linear regression. The linearity test uses the help of SPSS version 25.

The data analysis in this study include: (1) Product Moment correlation test. Product Moment correlation test is used to determine whether there is a correlation between two interval type variables (Misbahuddin, 2013; Sugiyono, 2014). The product moment correlation test is performed using tthe SPSS version 25 assistance. (2) Coefficient of Determination, to express the small contribution of variable $\mathrm{X}$ (number sense ability) to variable $\mathrm{Y}$ (mathematical problem solving ability).(3) Significance test, the significance test is carried out to find out the magnitude of the relationship between independent variables using the t-test, in this study the $\mathrm{t}$-test uses SPSS version 25. With the testing rule that is if $\mathrm{t}$-count $\geq \mathrm{t}$-table then accept the hypothesis that there is a significant correlation between students' number sense and their mathematical problem solving abilityand (4) Analysis of Linear Regression Test conducted to 
test whether or not the relationship between two variables is significant through its regression coefficient. In this study the linear regression test was carried out using the SPSS version 25 computer program.

\section{RESULTS AND DISCUSSION}

\section{Results}

\section{Students' number sense}

Students' number sense was measured based on the five indicators. The summary of students' number sense was presented in table 1 as follows:

Table 1. Students' Number Sense Based on The Five Indicators

\begin{tabular}{lc}
\hline Number sense indicators & Average Score \\
\hline Number concept & 51 \\
Multiple representation & 35 \\
Effect of Operations & 59 \\
Equivalent expressions & 23,6 \\
Compulating and counting strategies & 47,6 \\
\hline
\end{tabular}

From the five indicators of number sense ability, the ability of effect of operations is the ability with the highest test score. This was indicated by the questions regarding assessing whether the numbers obtained as a result of operations make sense, there are more than $70 \%$ of students who answered correctly. However, the indicator of the ability of number sense to get the lowest value is the ability of equivalent expressions with the acquisition of an average value of only 23.6. It was indicate that more than $50 \%$ of students cannot answer correctly the four questions given. Less than $20 \%$ of students can answer correctly. This happens because students have difficulty recognizing and determining other expressions that are equivalent to given mathematical expressions. Especially for the question where students incorrectly determine the same result of $0.5 \times 720$, they on average answer option choice $\mathrm{D}$ which is 0.50 $\mathrm{x} 72$, while the correct answer is option $\mathrm{C}$ which is $720 \div 2$.

The average score of students' number sense was 43.15 and the standard deviation of 16.43. The score ranges between 10 to 85 . We present the detailed results on table 2 bellow : 
Table 2.Category of Students' Number Sense Ability

\begin{tabular}{llll}
\hline Category & Value & Frequency & Percentage\% \\
\hline Very High (advance) & $75<\mathrm{N} \leq 100$ & 1 & 1,37 \\
\hline Height & $64<\mathrm{N} \leq 75$ & 8 & 10,96 \\
\hline Medium (intermediate) & $53<\mathrm{N} \leq 64$ & 13 & 17,81 \\
\hline Low & $0 \leq \mathrm{N} \leq 53$ & 51 & 69,86 \\
\hline Total & & 73 &
\end{tabular}

Based on table 2, it shows that students' number sense is in a low category. The students only could give correct answers to a half of the number sense tasks.

\section{Students' mathematical problem solving}

Students' mathematical problem solving was measured using 20 open-ended questions. The questions consist of four mathematics domains, namelly numbers, fractions, geometry , and measurements. We present the summary of students' mathematical problem solving on the table 3 bellows:

Table 3. Students' Mathematical Problem Solving Based on Four Mathematichal Domains

\begin{tabular}{cc}
\hline The Mathematical Domains Of Prolem & Average Score \\
Solving & 65 \\
\hline Number & 49 \\
Fractions & 37 \\
Measurement & 31 \\
Geometry & \\
\hline
\end{tabular}

From table 3, it is obvious that students' problem solving on the domain of numbers has the highest average score of 65 , where the average student has been able to solve the problem with the existing steps regarding numbers. However, students' problem solving on the domain of geometry has the lowest score, which is only 31 . This happens because the average student does not know the formula and how to solve problems related to geometry. 
Students' mathematical problem solving scores between 7.89 and 81.58 . The average score of students' mathematical problem solving was 46.03 and the standard deviation (SD) of 17.33. We present the detailed results on table 4 bellows:

Table 4. Categories of Students' Mathematical Problem Solving

\begin{tabular}{llll}
\hline Category & Value & Frequency & Percentage\% \\
\hline Very High (advance) & $75<\mathrm{N} \leq 100$ & 3 & 4,11 \\
\hline Height & $64<\mathrm{N} \leq 75$ & 11 & 15,07 \\
\hline Medium (intermediate) & $53<\mathrm{N} \leq 64$ & 12 & 16,44 \\
\hline Low & $0 \leq \mathrm{N} \leq 53$ & 47 & 64,38 \\
\hline Total & & 73 & 100 \\
\hline
\end{tabular}

Based on table 4, it shows that students' mathematical problem solving is in a low category. Most students could only solve less than a half of the problems.

\section{Hypothesis test}

Hypothesis testing in this study uses the Pearson product moment correlation test. The correlation test result using SPSS version 25 can be seen in table 5 below

. Table 5. The Correlation Test Results For Students' Number Sense (X) and Their Mathematical Problem Solving (Y)

\begin{tabular}{lll}
\hline & & Mathematical Problem Solving \\
\hline Number Sense & Person Correlation & $.634^{* *}$ \\
& Sig. (2-tailed) & .000 \\
& $\mathrm{~N}$ & 73 \\
\hline
\end{tabular}

Based on table 5 the results of the correlation test obtained r- count of 0.634 . This result indicates that there is a high correlation at the 0.01 level between students' number sense and their mathematical problem solving. To find out the significance of the correlation coefficient of students' number sense with their mathematical problem solving, we present the result on table 6 below. 
Table 6. Test Results Significance of Number Sense Ability with Mathematical Problem Solving Ability

\begin{tabular}{|c|c|c|c|c|}
\hline $\begin{array}{lr}\text { Number } & \text { sense } \\
\text { ability } & \text { with } \\
\text { mathematical } & \end{array}$ & tcount & t table & $\begin{array}{l}\text { Determination } \\
\text { Coefficient } \\
(\%)\end{array}$ & Remarks \\
\hline $\begin{array}{l}\text { problem solving } \\
\text { ability }\end{array}$ & 6,91 & 1,66 & 40,20 & $\begin{array}{l}\text { There is a significant } \\
\text { correlation }\end{array}$ \\
\hline
\end{tabular}

Table 6 shows the results of the significance test of students' number sense with their mathematical problem solving. $t_{\text {count }}(6.91)$ is greater than $t_{\text {table }}(166)$, and it can be concluded that there is a significant correlation between students' number sense and their mathematical problem solving. Table 6 also shows the results of the coefficient of determination between students' number sense their mathematical problem solving. The result shows that the students' number sense contributes to their mathematical problem solving by $40.20 \%$ and the remaining $59.80 \%$ is determined by other factors.

Beside looking the main correlation between students' number sense and their mathematical problem solving, we also investigate the correlation each number sense indicator with four mathematical domains of problem solving. We present the results on table 7 bellow

Table 7. Correlation Test Results for Number Sense Ability Indicators with Mathematical Problem Solving Ability Material

\begin{tabular}{lllll}
\multirow{2}{*}{$\begin{array}{c}\text { Number Sense } \\
\text { Indicators }\end{array}$} & \multicolumn{4}{c}{$\begin{array}{c}\text { The Correlation Coefficient }\left(\mathbf{r}_{\mathbf{x y}}\right) \text { with Content } \\
\text { Mathematical Problem Solving Capabilities }\end{array}$} \\
\cline { 2 - 5 } & Numbers & Fractions & Measurements & Geometries \\
\hline Number concept & 0,168 & $0,331^{* *}$ & $0,385^{* *}$ & $0,430^{* *}$ \\
\hline Multiple representation & 0,218 & $0,303^{* *}$ & $0,315^{* *}$ & $0,353^{* *}$ \\
\hline Effect of operations & 0,136 & $0321^{* *}$ & 0,172 & 0,042 \\
\hline Equivalent expressions & 0,026 & $0,249^{*}$ & 0,159 & 0,201 \\
\hline Counting and & $0,503^{* *}$ & $0,542^{* *}$ & $0,566^{* *}$ & $0,385^{* *}$ \\
compulating strategies & & & & \\
\hline
\end{tabular}


Based on the table 7, the correlation indicator ability number sense has the lowest level of correlation coefficient with the ability to solve mathematical problems is the number material, where the average number sense ability indicator does not have a significance level with the number material except counting and compulating indicator strategies that have values correlation of 0,503 with a significant level is quite high. While the correlation indicator ability number sense has the highest level of correlation coefficient with the ability to solve mathematical problems is fraction material, where the overall indicator ability number sense has a significance level with fraction material.

The highest correlation indicator between the 20 correlation tests of all number sense ability indicators and all material problem solving abilities that have the highest correlation value is the strategic counting and compulating correlation indicator with measurement material, where the correlation value obtained is $0.566^{* *}$ with quite high interpretation. While the one with the lowest value is the equivalent expression indicator correlation test with material numbers, the correlation value obtained is only 0.026 with very low interpretation.

\section{Linear Regression Analysis}

Linear regression test is performed to test whether or not the correlation between two variables is significant through its regression coefficient (Misbahuddin and Iqbal, 2014). Regression analysis is intended to determine the extent to which a variable influences other variables or several other variables (Suntoyo, 2013). The results of the linear regression test between students' number sense and their mathematical problem solving are presented on figure 1 bellows:

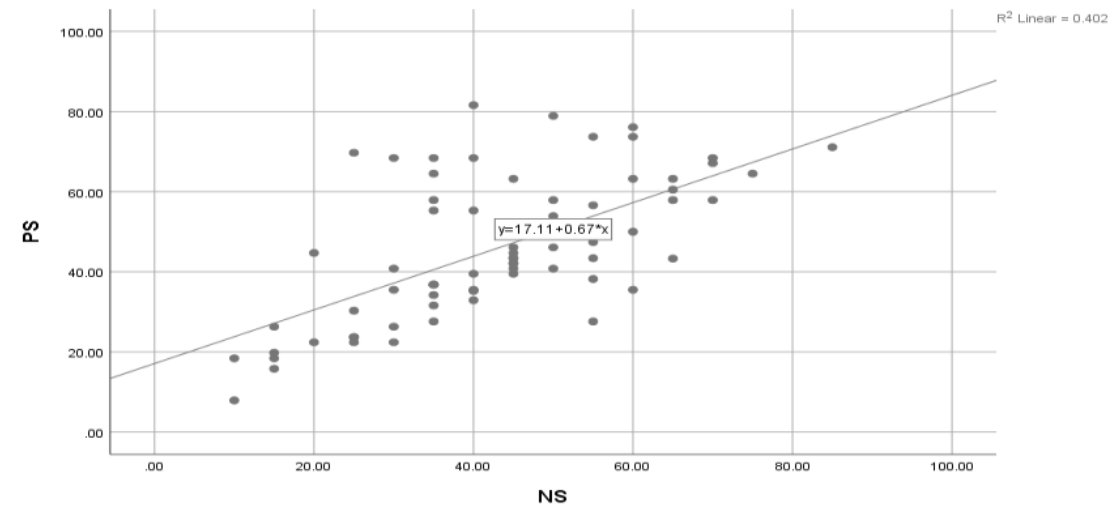

Figure 1. Graph of Regression Linearity Test Results 
Based on figure 1, The regression equation between students' number senseand their mathematical problem solving can be modelled as $\mathrm{Y}=17,105+0,669 \mathrm{X}$. With these equations it is known that students' mathematical problem solving well can be estimated if the ability of a good number sense. The value of $b=0,669$ means that each $1 \%$ increase in the level of students' number sense (X), then students' mathematical problem solving (Y) will increase by 0.669 . This linear line equation shows that the regression coefficient value is positive (+) so it can be said that students' number sense $(\mathrm{X})$ has a positive effect on their mathematical problem solving (Y).

\section{Discussion}

Based on the results of research and data analysis, it can be seen that the fifth grade students have low number sense abilities and math problem solving, where students' number sense has an average of 43.18, and their mathematical problem solving has an average of 46.03. This is illustrated from the number sense ability test given, students can only work on questions in the form of numbers but when given a variety of questions they have difficulty in doing it. The reason for the weak ability of students' number sense because learning in primary school is more emphasis on calculation than on understanding the number and concepts themselves.

This finding is in line with what Cross et al (in Susilowati, 2015) said that, numbers sense is expressed as the linkage of knowledge about numbers and their operations where it occurs due to a combination of a person's basic number sense knowledge which then increases due to experience and teaching. While students' mathematical problems is low due to the inability of students to understand the purpose and objectives of a given problem so they cannot determine the steps of solving problem solving by indicators of problem solving steps. The result of this study also indicates that there is a positive correlation between students' number sense and their mathematical problem solving. The two variables have a high correlation. This study also shows that an increase in students' number sense will be followed by an increase in their mathematical problem solving (the higher the number sense ability, the higher the ability of solving mathematical problems) and vice versa. This means that students 'mathematical problem solving can be improved through students' number sense. This is also reinforced by the opinion of Safitri et al., (2017) who say that students who have good number sense abilities will be able to use their understanding of numbers to solve mathematical problems that are not limited by traditional algorithms or procedures. 
The results of the study showed that there was a positive relationship between number sense ability and mathematical problem solving abilities, where the number sende ability and the mathematics problem solving ability of fifth grade elementary school students were still the same in this low category in line with previous research. Among them is research conducted by Nurhanida et al., (2017) which focuses on the number sense ability of fifth grade elementary school students which shows that the number sense ability of students is in the low category with an overall percentage of $49.88 \%$, especially in deciding wisely from the results of calculations through different strategies. . In addition, Trisnawati (2017) also conducted research that focused on the mathematics problem solving abilities of fifth grade students in elementary schools with the results showing that students' math problem solving abilities were still low with an overall score of less than 68 .

Of the test of correlation between each indicator of students' number sense and each domain of problem solving task that has been explained previously, the indicator of students' strategic computing and counting has the highest correlation to students problem solving in the domain of measurement. Moreover the one with the lowest correlation is the indicator of students' equivalent expressions with their problem solving in the domain of numbers. The students are less able to do mathematical reasoning so that they are complicated to solve mathematical problems, especially the problem solving of mathematical numbers.

\section{CONCLUSION}

Number sense is believed to be capital important for supporting the future development of students' mathematical thinking and its application. Students' low number sense could be a problem for the students to learn more advance mathematical problems, including mathematical problem solving. Through this study, we have shown that fifth grade students have difficulties to solve the tasks related to number sense and problem solving on four domains, numbers, fractions, geometry, and measurement. Students' low number sense affects their performance on mathematical problem solving task. Therefore, we like to suggest further study to develop and design a learning trajectory that could support students' number sense because students' number sense has a positive correlation to their mathematical problem solving. 


\section{REFERENCES}

Amirulloh, A. F., \& Budiarto, M. T. (2013). Kemampuan number sense siswa kelas VII SMP dilihat dari perbedaan jenis kelamin. MathEdunesa, 2(1), 69-77.

Habibah, U. (2016). Hubungan kreativitas dengan kemampuan problem solving pada siswa di MTs Al Musthofa Mojokerto. UIN Sunan Ampel Surabaya.

McIntosh, A., Bana, J., \& Farrell, B. (1997). Assessing number sense: collaborative initiatives in Australia, United States, Sweden and Taiwan. People in Mathematics Education, 320-330.

McIntosh, A., Reys, B. J., \& Reys, R. E. (2005). A proposed framework for examining basic number sense. In Subject Learning in the Primary Curriculum: Issues in English, Science and Mathematics. https://doi.org/10.4324/9780203990247

Misbahuddin, I. H. (2013). Analisis Data Penelitian dengan Statistik Edisi ke-2. Jakarta: Bumi Aksara.

Nurhanida, N., Witri, G., \& Alpusari, M. (2017). Analisis kemampuan number sense siswa kelas V SD Sekecamatan Tampan Pekanbaru. Jurnal Online Mahasiswa Fakultas Keguruan Dan Ilmu Pendidikan, 4(1), 1-14.

Polya, G. (1983). How to solve it. New Jersey: Princeton University Press.

Posamentier, S. A., \& Krulik, S. (2009). Problem solving in mathematics, grades 3 - 6. United States of America: SAGE.

Purnomo, Y. W. (2013). Mental computing to support smooth counting of addition and subtraction operations in elementary school students. In National Seminar on Mathematics and Mathematics Education. FMIPA UNY.

Putra, Z. H., Darmawijoyo, D., Putri, R. I. I., \& den Hertog, J. (2011). Supporting first grade students learning number facts up to 10 using a parrot game. Journal on Mathematics Education, 2(2), 163-172.

Putra, Z. H., \& Witri, G. (2019). Scientific contexts in pre-service elementary teacherdesigned mathematics picture books. In Journal of Physics: Conference Series (Vol. 1351, pp. 1-7). https://doi.org/10.1088/1742-6596/1351/1/012053

Robson, A., \& Polya, G. (1946). How to Solve It. The Mathematical Gazette, 30(290). https://doi.org/10.2307/3609122

Safitri, A. S., Mulyati, S., \& Chandra, T. D. (2017). Kemampuan Number Sense Siswa Sekolah Menengah Pertama (SMP) Kelas VII pada Materi Bilangan. In Prosiding SI MaNIs (Seminar Nasional Integrasi Matematika dan Nilai-Nilai Islami) (pp. 270-277).

Soedjadi, S. (2000). Kiat Pendidikan Matenatika di Indonesia. Jakarta: Dirjen DIKTI DEPDIKNAS.

Sugiyono. (2014). Metode penelitian pendidikan: Pendekatan kuantitatif, kualitatif, dan $R \& D$. Bandung: Penerbit Alfabeta. 
Susilowati, T. (2015). The ability of number sense through the method of learning by playing. Jurnal Pendidikan Dasar, 6(2), 324-335. https://doi.org/https://doi.org/10.21009/JPD.062.14

Syahlan, S. (2017). Sepuluh strategi dalam pemecahan masalah matematika. Indonesian Digital Journal of Mathematics and Education, 109-116.

Tonra, W. S. (2016). Pembelajaran number sense untuk meningkatkan hasil belajar siswa sekolah dasar pada materi pecahan. Matematika, Delta-Pi: Jurnal Matematika Dan Pendidikan, 5(2), 109-116.

Trisnawati, T. (2017). Analisis kemampuan pemecahan masalah matematis siswa tingkat sekolah dasar di Kotamadya Yogyakarta. Science Tech: Jurnal Ilmiah Ilmu Pengetahuan Dan Teknologi, 3(1), 1-10.

Umar, W. (2016). Strategi pemecahan masalah matematis versi George Polya dan penerapannya dalam pembelajaran matematika. Kalamatika: Jurnal Pendidikan Matematika, 1(1), 59-70.

Witri, G., Putra, Z. H., \& Nurhanida, N. (2015). Analisis kemampuan number sense siswa sekolah dasar di Pekanbaru. In Mahdum, S. S. Achmad, A. R. Ahmad, M. H. M. Yasin, D. A. Natuna, \& Suarman (Eds.), Proceeding 7th International Seminar on Regional Education (Vol. 2, pp. 755-762). Pekanbaru.

Yang, D. C., Hsu, C. J., \& Huang, M. C. (2004). A study of teaching and learning number sense for sixth grade students in Taiwan. International Journal of Science and Mathematics Education, 2(3), 407-430. https://doi.org/10.1007/s10763-004-6486-9 